\title{
Steel Plows and Iron Men: The Illinois Central Railroad and Iowa's Winter of 1936
}

Donovan L. Hofsommer

The weather is a topic which is always on the minds of Iowans. Perhaps they have spent more time talking about it than they have devoted to any other subject. In the summer Iowans are concerned with hot days and humid nights; in the spring they speculate when the ice "will go out" of the rivers and lakes and when the frost "will go out" of gravel roads; fall brings fear of an early frost; and, of course, winter suggests wind and snow-blizzards. It is this latter topic which commands the greatest attention of all. Epic blizzards of earlier years are recalled, and contemporary storms are measured against them. For the old-timers, no series of storms compares to that of 1936. Indeed, the difficulties brought on by the seemingly unending series of storms during January and February of that year are without parallel. Transportation services ground to a halt, were resurrected, and then stalled again as one blizzard was replaced by another. On the Minneapolis \& St. Louis Railroad, service north of Storm Lake was terminated for a full month while men and machines labored to open the line. Meanwhile, citizens of Rembrandt shivered in the absence of coal for their furnaces. Of Iowa's many railroads, possibly none suffered more, or responded more splendidly, than did the Illinois Central. On March 25, 1936, a weary W. S. Williams, Superintendent of the IC's Iowa Division wrote a twelvepage, singled-spaced resume describing that road's battle against the elements during the previous two-month period.

Williams' report related a tale of steel plows and iron men. He noted that prior to January 19 , Iowa had experienced a relatively 
mild winter. However, on that date at Waterloo the temperature dropped to twenty-four degrees below zero and the wind began to churn. By January 23 snow was falling and drifting across the IC's entire Iowa Division. Unhappily, it was merely the harbinger of things to come. During the entire storm period, which did not end until February 27, a total of fifty-one Illinois Central trains became snowbound in Iowa-eleven on one day alone. During the month of February, no fewer than 172 snow plow trains were dispatched by the IC at a cost of 20,000 depression dollars. During the same month, the railroad hired dozens of extra laborers who were put to work as snow shovelers; their wages, meals, and lodging amounted to an additional $\$ 67,000$. Meanwhile, other laborers installed 15,400 lineal feet of snow fence to supplement similar fences which had been erected during the previous fall. In sum, the Illinois Central virtually waged war against wind and snow in that ferocious winter of 1936.

Superintendent Williams' "war report" detailed the combat in chronological order. The following excerpts give an idea of the severe difficulties faced by the IC and its hardy employees. ${ }^{1}$

January 22-Train \#73, 18 loads and 19 empties, became stuck in the snow one mile west of Parkersburg. It was extricated eight hours later by a snow plow train.

Train \#575, 22 loads of stock, became stuck one mile east of Babcock (near Waverly). It was extricated by a snow plow train with the assistance of an extra gang. Building paper was applied to the north side of the cars at Waverly to keep the stock from freezing. Train \#72, 35 loads, became stuck in a drift near Sherwood (west of Rockwell City). Delay: 5 hours and 10 minutes.

Train \#75, 17 loads and 9 empties, left train on siding at Knierim because of heavy drifting.

Train \#442 and Extra 1805 both became stuck on the Cedar Rapids branch. Line blocked for 28 hours and 50 minutes.

Train \#72, 25 loads, became stuck at Reinicker (west of Blairsburg). Delayed 5 hours and 7 minutes.

${ }^{1}$ Report of W. S. Williams, Superintendent, Iowa Division, Illinois Central Railroad, Waterloo, Iowa (March 25, 1936), 12 pages. 
Train \#16 (passenger) 7 cars, stalled in a drift near Jesup. It was freed after four hours by Extra 298 and 30 snow shovelers.

Train \#673, 17 loads and 17 empties, stalled in the snow 21/2 miles east of Storm Lake. Delayed over 3 hours.

Train \#71, 29 loads and 1 empty, stalled in snow east of Iowa Falls. Delayed $61 / 2$ hours.

Train \#66, 21 loads and 1 empty, stalled in snow at Sherwood (west of Rockwell City). Delayed 2 hours and 10 minutes.

An embargo against the movement of livestock from Missouri River points was instituted at 2:45 p.m. but lifted at 9:30 a.m. on the following day.

February 3-Train \#691, 11 loads and 4 empties, became stuck near Sulphur Springs. Line closed for 6 hours and 40 minutes. Train \#712, 2 loads, freed by a doubleheader plow train after being entrapped by snow near George for 7 hours and 5 minutes. Train \#776, 11 loads, became stuck near Bruce (Minnesota, on the Sioux Falls line). Released after 7 hours.

Train \#74, 1 load and 56 empties, stalled near Macy (east of Iowa Falls). Line closed for 24 hours.

February 8-Temperatures over the Iowa Division ranged from 16 to 25 degrees below zero. Suddenly the wind picked up and it began to snow heavily.

Train \#672, 6 loads, stalled near Marcus. A futile attempt to free it was made by a snow plow and a gang of men. Two days later another attempt was made by a doubleheader snow plow but, unhappily, it crashed into the stalled train. Line blocked for 80 hours.

Train \#73, 17 loads and 5 empties, stalled in snow one mile east of Rockwell City. Going to the rescue, a doubleheader plow train similarly became stuck and the locomotives had to be abandoned. Meanwhile, yet another snow plow train stalled at Knierim. On the 9 th, even another doubleheader plow train failed to open the line and turned back to Fort Dodge from Richards. Two engines coupled, with the assistance of a Russell Plow and a Jordan Spreader, extricated \#73 on the 10th and, with the assistance of a third locomotive, freed the stalled doubleheader plow train on the 


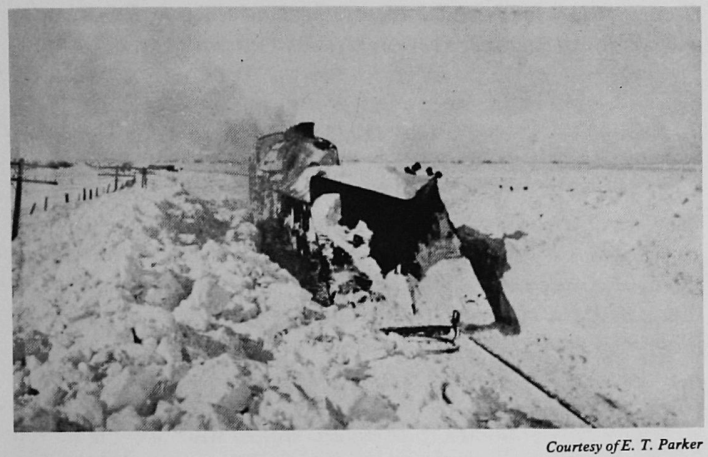

Train \#672 stalled in the snow west of Marcus in the early hours of February 8 -it was not extricated until two days later. The IC's Sioux City line was finally opened on the 11th, after being closed for 79 hours and 38 minutes.

11th. By then the Omaha line had been blocked for over 81 hours. Train \#611 (passenger), following directly behind a snow plow extra, stalled in the snow west of Sulphur Springs. A relief train extricated \#611's sleeper and returned it with 30 passengers to Fort Dodge. Another relief train retrieved \#611's locomotive but the rest of its train remained stalled. Line cleared at 4:00 p.m. on the 9 th after being closed for nearly 32 hours.

Train \#542, 6 loads (and two Waterloo passengers in the caboose), stalled near Plainfield. A relief train became stuck near Babcock (south of Waverly) on the 9 th and had to be abandoned. Passengers from \#542 were taken to Plainfield by bobsled. Line opened after 68 hours.

Beginning during the night of the 7th and lasting until the morning of the 11th, no revenue traffic moved over the IC's main line between Fort Dodge and Waterloo. On the 8th, an embargo was levied against all perishable and livestock traffic. The embargo was not lifted until the afternoon of the 11th.

February 13-A new storm caused the IC to annul all trains on the western portion of the division which were not already out of their terminals. Livestock consigned to an Austin, Minnesota, packer, amounting to 31 cars, was unloaded at South Omaha. 
Train \#791, 9 loads and 1 empty, became stuck at Edna (southeast of Rock Rapids). It was extricated 22 hours later.

February 14-The IC's Fort Dodge-Waterloo section was closed for $10^{1 / 2}$ hours near Macy (east of Iowa Falls) due to heavy drifting.

Engines 3890-1820 with a wedge plow became stuck 3 miles west of Rockwell City. They were released 4 hours later by engines 1876-1882 and a Russell Plow.

Train \#60, 5 loads and 7 empties, stalled in the snow at Delaware. Delayed 1 hour.

February 17-Train \#16 (passenger), stalled west of Marcus. The passengers were taken to town by bobsled. Two snow plow extras, one from Cherokee and one from Sioux City, went to the rescue. Number 16 delayed $9 \frac{1}{2}$ hours.

Extra 1521, with Supervisor Moss and 120 men attempted to dig out the dozens of switches between Fort Dodge and Council Bluffs. In the afternoon their engine and plow became stuck in a drift near Rockwell City. Shortly thereafter one of their cabooses was derailed. Line cleared after 9 hours. Of Moss's crew, 20 men suffered frozen hands, feet, and faces requiring medical attention. Later, after midnight, engines 1521-1817 were stalled in the snow east of Rockwell City for four hours.

Train \#771 stalled 4 miles north of Cherokee. A switch engine from Cherokee retrieved the train.

Extra 1676, 15 loads and 12 empties, stalled one mile from Babcock (south of Waverly). Line closed for 16 hours.

Train \#542, 10 loads, became stuck in the snow 3 miles south of Orchard. Train delayed for 22 hours.

February 26-Snow plows ran ahead of all IC trains in a supreme effort to keep the Iowa lines open. It was fruitless.

Train \#711, 2 loads, stalled near Ben Clare (South Dakota, on the Sioux Falls line) and was delayed for $4 \frac{1}{2}$ hours.

Extra 1957, 8 loads and 55 empties, stalled near Ulmer but eventually extricated 18 of its cars and tried to get them into a siding. However, it stalled again with the result that the line was blocked 


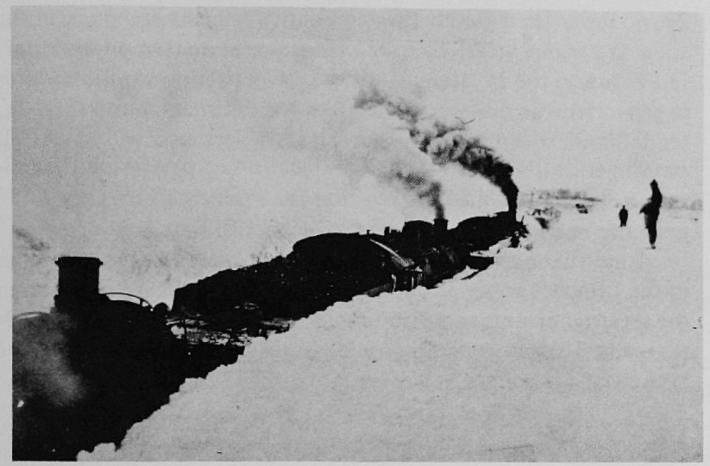

Courtesy of E. T. Parker

It took a tripleheader (locomotives 1824-1881-1848) to relieve the Jordan Spreader and locomotives 1521-1823 which had stalled three-and-one-half miles west of Rockwell City, February 11, 1936.

with two pieces of Extra 1957's train. The train crew reported that drifts ranged up to 15 feet in depth between Ulmer and Knierim. Engines 3890-3818 coupled attempted to free Extra 1957 but instead became stuck themselves near Yetter. When the water supplies were exhausted, engine crews killed the fires on both locomotives.

Train \#15 (passenger), was held at Marcus because the line was closed west of that station. Plows succeeded in opening the route after it had been blocked for over 28 hours.

Train \#72, 60 empties, stalled at Reinicker (west of Blairsburg). A snow plow extra and 50 men relieved \#72 after $201 / 2$ hours. Train \#541, plow and caboose only, became stuck at Stacyville Junction and was not extricated until 19 hours later.

Extra 3888 and Extra 1904 together relieved Extra 1957 at Ulmer and Engines 3890-3818 at Yetter. However, they did not finish the task until the 27th, when the Omaha line had been closed for nearly 31 hours.

The Des Moines Register hailed Iowa's winter weather of 1936 
as the worst in 117 years of recorded history. On one day, January 23, no fewer than eleven Illinois Central trains were stuck in the snow at various locations in the Hawkeye State. On another day, in February, the IC assigned as many as twenty-two locomotives to snow clearing tasks in Iowa. Between February 9 and the 21st, ten laborers equipped with snow shovels were assigned to ride all passenger trains west of Waterloo. Veteran employees on the railroad's Sioux Falls line asserted that the storms of February 26-27 were the most devastating ever witnessed in that area.

A number of fierce winter onslaughts have troubled the lines of the Illinois Central in Iowa in past years, yet none compare to the severity, extent, and duration of the storms in 1936. Railroaders-and Iowans generally-are not eager that the records be broken.

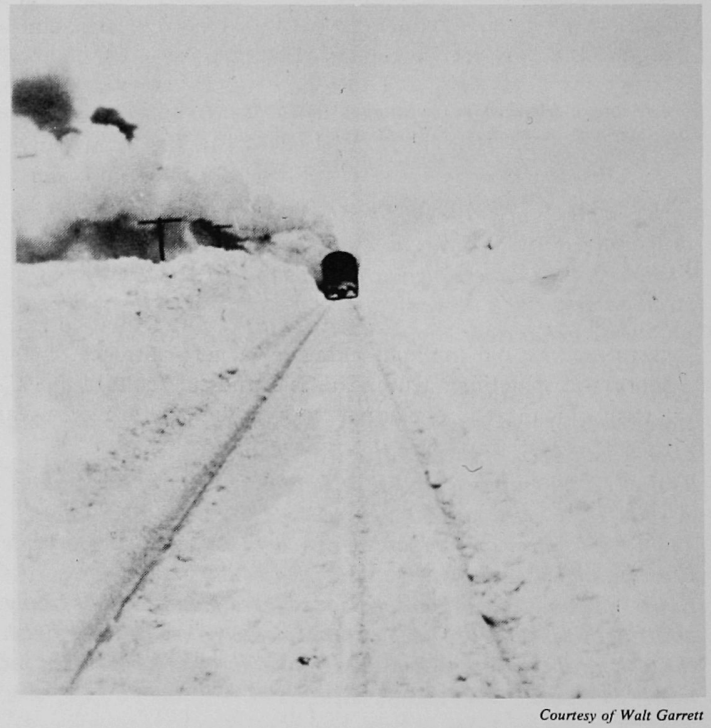

The two struggling locomotives in the distance have just opened the IC's Omaha line near Richards in February, 1936. 
Copyright of Annals of Iowa is the property of State of Iowa, by \& through the State Historical Society of Iowa and its content may not be copied or emailed to multiple sites or posted to a listserv without the copyright holder's express written permission. However, users may print, download, or email articles for individual use. 